\title{
Evidence for Mid-Holocene Change in Depositional Style in Mobile Bay, Alabama
}

Open-File Report 2012-1081 



\section{Evidence for Mid-Holocene Change in Depositional Style in Mobile Bay, Alabama}

By David Twichell, Kyle Kelso, and Elizabeth Pendleton

Open-File Report 2012-1081

U.S. Department of the Interior

U.S. Geological Survey 


\section{U.S. Department of the Interior \\ KEN SALAZAR, Secretary}

\section{U.S. Geological Survey \\ Marcia K. McNutt, Director}

U.S. Geological Survey, Reston, Virginia: 2012

For more information on the USGS-the Federal source for science about the Earth, its natural and living resources, natural hazards, and the environment-visit http://www.usgs.gov or call 1-888-ASK-USGS

For an overview of USGS information products, including maps, imagery, and publications, visit $h$ ttp://www.usgs.gov/pubprod

To order this and other USGS information products, visit http://store.usgs.gov

Suggested citation:

Twichell, David, Kelso, Kyle, and Pendleton, Elizabeth, 2012, Evidence for mid-Holocene shift in depositional style in Mobile Bay, Alabama: U.S. Geological Survey Open-File Report 2012-1081, 17 p., available at http://pubs.usgs.gov/of/2012/1081/.

Any use of trade, product, or firm names is for descriptive purposes only and does not imply endorsement by the U.S. Government.

Although this report is in the public domain, permission must be secured from the individual copyright owners to reproduce any copyrighted material contained within this report. 


\section{Contents}

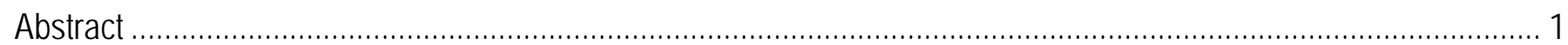

Introduction

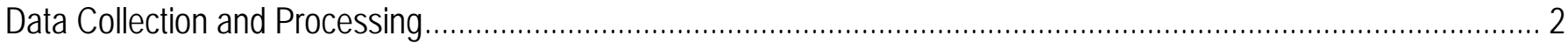

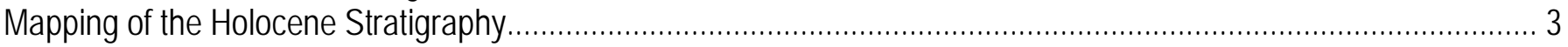

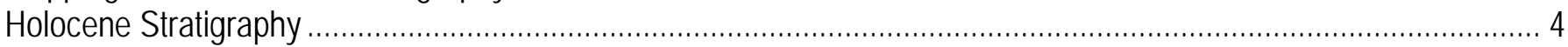

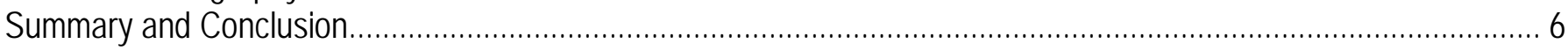

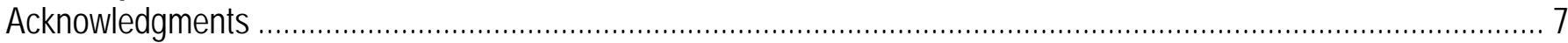

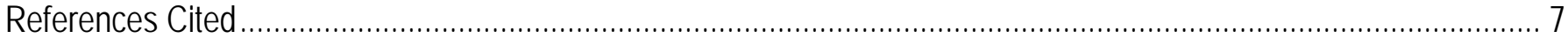

\section{Figures}

1. Map showing the bathymetry of Mobile Bay, Alabama, the paths of lowstand river valleys as interpreted by three authors, the extent of Pleistocene deposits around the bay, and the location of three sets of Holoceneaged beach ridges on Morgan Peninsula

2. Map showing the extent of the seismic data and cores collected in 2010 and the tracks along which analog seismic data were collected in 1990

3. Seismic profile and interpretation showing the Holocene stratigraphy of the bay above the last glacial maximum surface

4. Map showing the depth to the erosional surface cut during the last glacial maximum

5. Map showing the depth to the top of the mid-Holocene R1 unit and the variations in reflection amplitude from the R1 unit....

6. Seismic profiles showing (A) variations in reflection amplitude of the R1 unit and how it onlaps the bay side of Morgan Peninsula, (B) an east-west profile showing the flat-lying nature of unit R1 and that it pinches out on the last glacial maximum surface along the edges of the bay, and (C) a crossing of the northwestern submerged extent of the Little Point Clear peninsula............................................................................14

7. Vibracores from Bon Secour Bay showing variations in sediment composition associated with the R1 unit ...15

8. Isopach map showing the thickness of Holocene deposits in Mobile Bay, Alabama 16

9. Isopach maps showing (A) the thickness of early Holocene deposits that accumulated between the last glacial maximum and R1 surfaces and (B) the thickness of late Holocene deposits that accumulated above the R1 surface 


\section{Conversion Factors}

SI to Inch/Pound

\begin{tabular}{|c|c|c|}
\hline Multiply & By & To obtain \\
\hline \multicolumn{3}{|c|}{ Length } \\
\hline centimeter $(\mathrm{cm})$ & 0.3937 & inch (in.) \\
\hline meter (m) & 3.281 & foot (ft) \\
\hline kilometer (km) & 0.6214 & mile (mi) \\
\hline kilometer (km) & 0.5400 & mile, nautical (nmi) \\
\hline meter $(\mathrm{m})$ & 1.094 & yard (yd) \\
\hline \multicolumn{3}{|c|}{ Area } \\
\hline square kilometer $\left(\mathrm{km}^{2}\right)$ & 247.1 & acre \\
\hline square kilometer $\left(\mathrm{km}^{2}\right)$ & 0.3861 & square mile $\left(\mathrm{mi}^{2}\right)$ \\
\hline \multicolumn{3}{|c|}{ Volume } \\
\hline cubic kilometer $\left(\mathrm{km}^{3}\right)$ & 0.2399 & cubic mile $\left(\mathrm{mi}^{3}\right)$ \\
\hline
\end{tabular}

\section{Abbreviations}

B.P. before present

FSSB full spectrum subbottom (profiler)

LGM last glacial maximum

USGS U.S. Geological Survey 


\title{
Evidence for Mid-Holocene Change in Depositional Style in Mobile Bay, Alabama
}

\author{
By David Twichell, Kyle Kelso, and Elizabeth Pendleton
}

\begin{abstract}
The Holocene stratigraphy of Mobile Bay, Alabama, was mapped using a combination of high-resolution seismic data and sediment cores to refine changes in the bay's evolution during this time. The base of the Holocene-era stratigraphy is an erosional surface formed during the last glacial maximum. Overlying Holocene deposits are primarily estuarine mud that has a finely laminated weak acoustic signature. One exception is a thin unit, R1, with varying reflection amplitude that can be traced throughout the southern part of the bay. The continuity of the unit throughout the southern part of the bay suggests a baywide change in sedimentation that was perhaps driven by rapid retreat of the bay-head delta in response to a sudden rise in sea level or an abrupt change in accommodation space due to basin geometry. Along the southern edge of the bay, the R1 unit increases in thickness and reflector amplitude towards Morgan Peninsula. The peninsula itself underwent a period of erosion and narrowing between 4,300 to 3,000 years before present, and the variation in reflector amplitude and the geometry of this part of the R1 unit appear to reflect a period of increased overwashing of the peninsula during this period. Average estuarine sedimentation rates decreased after the formation of the R1 unit, and the decrease coincides with a decline in the rate of sea-level rise. A similar change in depositional style at approximately the same time in neighboring Apalachicola Bay suggests a change that affected the northeastern Gulf of Mexico region and not just Mobile Bay.
\end{abstract}

\section{Introduction}

Mobile Bay is the largest estuary in the northeastern Gulf of Mexico, and sedimentary deposits within the bay provide a record of its Holocene history. Presently, the bay is partially enclosed from the Gulf of Mexico by Dauphin Island to the west and the Morgan Peninsula to the east (fig. 1). The core of Dauphin Island comprises Pleistocene deposits; Morgan Peninsula was formed by spit elongation during the Pleistocene and Holocene (Otvos and Giardino, 2004, p. 68-69; Rodriguez and Meyer, 2006, p. 58-68). The westward elongation of Morgan Peninsula would suggest that, through the Holocene, Mobile Bay became more sheltered from the Gulf of Mexico with time, yet a study of beach ridges on the peninsula identified an erosional period when this barrier may have been breached, allowing coarser material to be transported into the bay (Rodriguez and Meyer, 2006, p. 64-66). Behind Morgan Peninsula, the Holocene deposits that fill Mobile Bay have been the focus of several studies. High-resolution seismic profiles have been used to map the unconformity cut by rivers during periods of lowered sea level (Mars and others, 1992, p. 538; Davies and Hummell, 1994; Kindinger and others, 1994, p. 86; Greene and others, 2007, p. 147; fig. 1). Holocene deposits that rest on this unconformity have been divided 
into two units, a basal sandy bay-head delta unit that fills the narrow deep paleovalleys and an overlying muddy estuarine unit that covers the entire bay floor (May, 1976, p. 6-14; Mars and others, 1992, p. 533-540; Greene and others, 2007, p. 143-153; Rodriguez and others, 2010). Rodriguez and Meyer (2006, p. 264-266) identified a silty to sandy interval within the muddy estuarine fill from a core in Bon Secour Bay, which they suggest was storm or tidal delta deposits that formed when the Morgan Peninsula was breached between 4,300 to 3,000 years before present (B.P.), but they could not define the full extent of these deposits with only one core and with limited seismic data.

The purpose of this study is to further refine the Holocene stratigraphy of the bay with particular emphasis on the presence and composition of potential storm deposits in the southern part of the bay. A reconnaissance grid of high-resolution seismic profiles and previously acquired seismic data were used to map Holocene sediment thickness throughout the bay and, where data quality was sufficient in the southern part of the bay, to refine the Holocene estuarine stratigraphy and its relation to Morgan Peninsula. Short vibracores were used to characterize the upper 4 to 5 meters (m) of the estuarine deposits, and published age dates (May, 1974, p. 12; Rodriguez and Meyer, 2006, p. 260; Greene and others, 2007, p. 143) were used to refine the history of the bay.

\section{Data Collection and Processing}

High-resolution seismic-reflection profiles were collected with a Geo-Star full spectrum subbottom (FSSB) Chirp system deployed in an SB-0512i towfish (0.5-12 kiloHertz frequency) (EdgeTech, undated) along 260 kilometers of survey trackline in the southern part of Mobile Bay during July 17-21, 2010, aboard the U.S. Geological Survey research vessel G.K. Gilbert. These data were logged digitally in SEG Y format (Norris and Faichney, 2002). Vibracores were collected from nine stations located along seismic profiles in the southern part of the bay on July 23, 2010, aboard the G.K. Gilbert (fig. 2). Differential Global Positioning System navigation was used during acquisition of seismic data and cores. The survey did not cover the entire bay, but analog seismic profiles collected by the U.S. Geological Survey (USGS) in 1990 employing an Ocean Research Equipment. Geopulse system were used to map the northern part of the bay and complimented the new dataset in the southern part of the bay.

SIOSEIS (undated), Seismic Unix (Stockwell and Cohen, 2007) and SeisVision (GeoGraphix, 2008) were used to process the raw Chirp seismic data. For digital interpretation, SEG Y trace data were imported into SeisVision, where reflectors representing the sea floor and key subsurface stratigraphic contacts were identified and digitized. The interpretations were exported from SeisVision as XYZ point files and imported into ArcMap (Environmental Systems Research Institute, Inc., 2011), where depth to the interpreted horizons was plotted. For the analog profiles, depth to the sea floor and other subsurface stratigraphic horizons was measured by hand, entered into a spreadsheet, and then imported into ArcMap. A 1,500-meter-per-second speed of sound was used to convert the vertical scale of the seismic data from milliseconds of two-way travel time to depths in meters. Point data were contoured by hand because of the wide spacing between the survey lines. The contours were digitized and then converted to a grid using the topo-to-raster tool in ArcGIS . Grid surface calculations were completed to compute the thickness and volume of different stratigraphic units. Vibracores were obtained in the Bon Secour Bay section of Mobile Bay by using a Rossfelder model P-3 coring system deployed from the G.K. Gilbert (fig. 2). Upon recovery, the aluminum barrel was removed from the rig and cut to 1-m lengths. The completed cores were transported to the USGS in St. Petersburg, 
Florida, for curation and description. Each core section was split vertically, visually described using standard sediment logging methods, and photographed. Core logs were generated to include a description of sedimentary texture, sedimentary structures, percent sand, physical characteristics, and stratification type.

\section{Mapping of the Holocene Stratigraphy}

The seismic profiles were used to map (1) the sea floor, (2) the unconformity interpreted to be cut by rivers during the last glacial maximum (LGM), and (3) a mid-Holocene thin unit, R1, with varying reflection amplitude that could only be mapped on the Chirp profiles collected in the southern part of the bay (fig. 3). Additional units associated with Morgan Peninsula were identified along the very southern margin of the bay. The sea floor was mapped on the profiles throughout the bay, whereas the subsurface horizons were mapped in the areas free of gas.

The coastal relief dataset compiled by the National Oceanic and Atmospheric Administration (2006) was used to characterize the bathymetry of Mobile Bay (fig. 1). The bay is shallow with most of it being less than $4 \mathrm{~m}$ deep. It is divided into eastern and western basins that are separated by the dredged ship channel that extends from the mouth of the bay to the port of Mobile at the head of the bay. The eastern basin reaches 4-m depths in the northeastern part of the bay. Bon Secour Bay, which composes the southeastern corner of Mobile Bay, is 2 to $3 \mathrm{~m}$ deep. The western basin occupies the southwestern part of the bay. This basin increases in depth toward the south and reaches $4 \mathrm{~m}$ deep near the bay entrance. Immediately behind the bay entrance, depths exceed $14 \mathrm{~m}$, and the dredged channel is mostly greater than $10 \mathrm{~m}$ deep.

The erosional surface that was cut during the last lowstand of sea-level, the LGM surface, is shown in figures 3 and 4 . At the head of the bay, borings show two shallow channels within the floor of a broader valley (Greene and others, 2007, p. 147). Available seismic data suggest that these two channels follow paths along the eastern and western margins of the northern and central parts of the bay where they are separated by a north-south trending plateau in the middle of the bay (fig. 4). The valleys converge, or nearly converge, in a broad basin that underlies the southern part of the bay. Differences in the paths of lowstand valleys published by Kindinger and others (1994, p. 86), Davis and Hummel (1994), and Greene and others (2007, p. 147) are in part due to gas masking the deeper stratigraphy under a large part of the central bay (fig. 2) and to insufficient seismic coverage to ensure that valleys were correlated with the correct Pleistocene lowstand (fig. 1).

On seismic profiles, the estuarine deposits that fill the bay show faint laminations that are separated into two major intervals by the thin R1 unit. The estuarine deposits underlying the R1 unit are characterized by laminations with low to moderate relative reflection amplitude, while the deposits above the R1 unit are characterized by laminations with very low relative reflection amplitude. The R1 unit could be identified only on Chirp seismic data, and thus the mapped extent of the unit is limited to the southern part of the bay (fig. 5). The R1 unit is limited to being a single reflector throughout the central and northern part of the study area and broadens to two to three reflectors along the southern edge of the bay (fig. 3) where it onlaps Pleistocene deposits behind Dauphin Island and early to mid-Holocene deposits that compose Morgan Peninsula (fig. 6A). Available data suggest that the surface of the R1 unit mimics the early Holocene estuarine deposits that floor the bay but does not drape up onto older deposits exposed at shallower depths along the bay margins (fig. 6B). Depth to the R1 surface is 7 to $10 \mathrm{~m}$ in the central and northern part of the study area (fig. 5). Limited Chirp coverage and gas preclude mapping the northern limit of the R1 unit. 
In addition to the distribution and depth of the R1 unit, relative reflection amplitude was mapped as well (fig. 5). Reflector amplitudes are highest on the profiles collected from Bon Secour Bay east of Little Point Clear and a smaller area off the western tip of Little Point Clear. Reflector amplitude decreases from these two areas northward into the bay. Moderate amplitude reflectors extend farthest northward in the western part of the bay. The northern limit of the low amplitude reflectors could not be mapped because of insufficient data coverage.

Cores that penetrate the R1 unit show that the unit coincides with a bioturbated, sandy shell bed that interrupts an otherwise muddy section (fig. 7A). The bed is thickest and sand content highest in the cores located in the high-amplitude region. The sand content of this bed decreases northward, and the one core in the moderate amplitude region that penetrated the R1 unit recovered shell hash at the depth of the R1 unit (fig. 7B).

The thickness of the Holocene sediment in the bay was mapped by taking the difference between the present sea floor and the depth to the surface cut during the LGM (fig. 8). Holocene sediment is thickest at the head of the bay and in the paleovalleys. Sediment filling the paleovalleys commonly is masked by gas, but in places free of gas, this interval is characterized by foreset bedding (fig. 3). This bedding is interpreted to represent bay-head deltas that retreated up the valleys in response to the rising sea. Bay-head deltas could not be mapped as a separate unit because of the extent of gas in the southern part of the bay and the lower resolution of profiles in the northern part of the bay. Borings through the thick Holocene section at the head of the bay indicate that much of this sediment is associated with the present-day Mobile-Tensaw Delta (May, 1976, p. 7-9; Greene and others, 2007, p. 146-147).

Immediately northwest of Little Point Clear, Holocene sediment reaches 8 to $10 \mathrm{~m}$ in thickness and is characterized by foreset bedding dipping primarily to the south (fig. 6C). Little Point Clear extended farther to the northwest earlier in the Holocene, and the southward dip of the foreset beds is presumably due to the southward accretion of beach ridges during the formation of this spit.

Holocene deposits overlying the basal bay-head delta unit are characterized by lowamplitude continuous acoustic reflections. The deposit is thickest in the south-central part of the bay where the two paleovalleys merge (fig. 8). The deposit is less than $4 \mathrm{~m}$ thick over the central plateau that separates the two paleovalleys and pinches out along the bay margins. Earlier cores (May, 1976, p. 4-21) and cores from this study indicate that this deposit is a silty clay that represents open-bay sedimentation (fig. 7).

The R1 unit divides the Holocene estuarine deposits into two units (fig. 9). In the southern part of the bay, Holocene sediment deposited prior to the deposition of the R1 interval first filled the paleovalleys and then spread more broadly across the bay floor (fig. 9A). The volume of the deposit below the R1 interval is 3.9 cubic kilometers $\left(\mathrm{km}^{3}\right)$. The unit overlying the R1 interval is thickest over the confluence of the two paleovalleys as well as over the valleys themselves (fig. 9B). The volume of sediment deposited above the R1 interval is $1.3 \mathrm{~km}^{3}$.

\section{Holocene Stratigraphy}

Holocene sedimentation in Mobile Bay shows a transition from bay-head delta sedimentation to fine-grained estuarine sedimentation (Greene and others, 2007, p. 143-152). The new seismic and core data collected for this study indicate that, at least in the southern half of the bay, the fine-grained estuarine deposits can be broken into two intervals separated by the R1 unit (fig. 5). This unit was sampled in Bon Secour Bay and dated at 4,300 to 3,000 years B.P. (Rodriguez and Meyer, 2006, p. 260-266). Drawing on that chronology and the seismic facies 
distribution of this horizon, we make inferences as to the origin of this thin sedimentary unit and use it to evaluate changes in Holocene sedimentation style and sedimentation rates in the southern part of the bay.

Sea level has risen approximately $20 \mathrm{~m}$ since the initial flooding of the bay, but the rate of sea-level rise has not been constant. Two recent curves of sea-level rise based on data from the northern Gulf of Mexico have been presented by Balsillie and Donoghue (2004) and Milliken and others (2008), showing that the average rate of sea-level rise decreased from 4 to 5 millimeters per year (mm/yr) before 8,000 to 7,000 years B.P. to between 1 and $1.4 \mathrm{~mm} / \mathrm{yr}$ by 7,000 to 4,000 years B.P., at and after 4,000 years B.P. the rate of sea-level rise slowed to less than $0.6 \mathrm{~mm} / \mathrm{yr}$ (Balsillie and Donoghue, 2004, p. 10; Milliken and others, 2008). The R1 unit, based on the age published by Rodriguez and Meyer (2006, p. 260-266), formed during the transition from a period of moderate sea-level rise to a period of slow sea-level rise. We used the volume of sediment that accumulated before and after the formation of the R1 unit along with dates of the LGM surface and R1 unit to calculate average sedimentation rates.

Approximately $8.2 \mathrm{~km}^{3}$ of sediment has accumulated during the Holocene in Mobile Bay (fig. 8). Of this, $5.2 \mathrm{~km}^{3}$ accumulated in the southern part of the bay covered by our highresolution seismic data (fig. 9). Of the $5.2 \mathrm{~km}^{3}$ that accumulated within the study area, $3.9 \mathrm{~km}^{3}$ accumulated below the R1 unit, covers an area of 590 square kilometers $\left(\mathrm{km}^{2}\right)$, and has an average thickness of $6.7 \mathrm{~m}$. The deposit overlying the R1 unit has a volume of $1.3 \mathrm{~km}^{3}$, covers an area of $476 \mathrm{~km}^{2}$, and has an average thickness of $2.7 \mathrm{~m}$. Using 9,600 years B.P. as the time the bay initially flooded (Greene and others, 2007, p. 151) and 4,300 to 3,000 years B.P. for the age of the R1 unit (Rodriguez and Meyer, 2006, p. 260-266), sediment accumulated at an average rate of 1.0 to $1.3 \mathrm{~mm} / \mathrm{yr}$ before the formation of the $\mathrm{R} 1 \mathrm{unit}$ and 0.6 to $0.9 \mathrm{~mm} / \mathrm{yr}$ since the time of the formation of the R1 unit. The higher accumulation rate during the early part of the history of the bay is attributed to the higher rate of sea-level rise during this time, which provided more accommodation space for sediment accumulation than was available later when the rate of sealevel rise slowed. Whether sediment input to the bay by the Mobile-Tensaw River system was greater during the early Holocene or whether sediment input was constant and more sediment bypassed the bay during the late Holocene due to a lack of accommodation space cannot be determined with the available data.

The R1 unit was first identified by Rodriguez and Meyer (2006, p. 264-265) in Bon Secour Bay and was inferred to represent either storm deposits sourced from the peninsula or a tidal delta that formed once the peninsula was breached. The broader suite of seismic profiles available from this study allowed mapping of the morphology, distribution, and seismic amplitude of this unit. The conclusions of the mapping from the study are more consistent with the unit being formed by storms. The deposit is only 1 to $3 \mathrm{~m}$ thick along its southern edge where it onlaps Morgan Peninsula and thins gradually to the north to a single reflection that can be traced throughout much of the southern half of the bay. Reflector amplitude decreases gradually to the north as well (fig. 3). The distribution of the high-amplitude reflectors suggests two source areas to either side of Little Point Clear with the area to the east being larger (fig. 5), which floors a shallow depression behind the narrow part of Morgan Peninsula. The thin nature of the deposit, its broad extent throughout the southern half of the bay, the largest high-amplitude area occupying a slight depression behind Morgan Peninsula, and the gradual decrease in the amplitude of the R1 unit towards the north are factors more consistent with a storm deposit than a tidal delta. 
A core from the high-amplitude area east of Little Point Clear penetrated a 50-centimeterthick bioturbated sand bed with shell fragments and may represent an overwash deposit (fig. 7A). The one core from the moderate-amplitude region that penetrated $\mathrm{R} 1$ recovered a thin shell bed from this interval (fig. 7B). This shell bed could either be a more distal part of the same storm overwash bed or a localized lag resulting from repeated resuspension and reworking of bay-floor sediments by storms. Isphording and Isphording (1991) noted that the floor of the bay deepened by approximately $0.5 \mathrm{~m}$ following the passage of Hurricane Frederic in 1979. While much of the resuspended material was exported from the bay, coarser shelly material in the estuarine deposits may have remained in the bay to form thin shell lag deposits.

Studies of cores recovered from lakes on Morgan Peninsula (Liu and Fearn, 1993), in northwestern Florida (Liu and Fearn, 2000), and in the Pearl River Delta, Mississippi (Li, 1994), found an increased abundance of coarser-grained laminations in muddy lake or delta deposits during the period between 4,000 and 3,000 years B.P. These coarser laminations are interpreted to be overwash deposits generated by storms. The timing for this period of increased storm activity coincides with and may be the cause of the period when the Morgan Peninsula underwent erosion, resulting in narrowing and possible breaching (Rodriguez and Meyer, 2006, p. 266-268). The R1 unit, which is of the same age, may show the response of the bay floor to this period of increased storm activity.

An alternative explanation is that the R1 unit is of composite origin. Throughout much of the bay, the R1 unit is a single reflector that may represent a change in sedimentation in the bay in response to a rapid retreat of the bay-head delta between 4,300 to 3,000 years B.P. Below the R1 unit, the fill is characterized by moderate amplitude reflections; above the unit, reflection amplitudes are low (figs. 2, 6A). A similar stratigraphy has been identified in Apalachicola Bay. There, sandy deltaic deposits and correlative deposits dating from before the formation of the delta show moderate amplitude reflections and are covered by fine-grained estuarine deposits that show low amplitude reflections (Twichell and others, 2010). The surface that separates the deltaic and correlative deposits from the estuarine deposits formed approximately 4,400 years B.P., and the stratigraphy suggests rapid shoreward migration of the deltas at this time (Osterman and others, 2009). The rapid retreat of the deltas in Apalachicola Bay may have been in response either to a slight but rapid rise in sea level (Balsillie and Donoghue, 2004, p. 1-23) or to the interaction of a gradually rising sea level with the geomorphology of the bay, resulting in a rapid increase in accommodation space (Rodriguez and others, 2008, p. 3983-3991). The stratigraphies of the two bays suggest a regional change that affected both bays in a similar way. The thicker part of the R1 unit along the southern edge of Mobile Bay appears to be storm deposits transported into the bay during the time (4,000-3,300 years B.P.) when both bays were also being subjected to rapid headward retreat of bay-head deltas.

\section{Summary and Conclusion}

The Holocene stratigraphy of Mobile Bay, Alabama, has been mapped using recently acquired high-resolution seismic data and cores complimented with historical datasets. The Holocene estuarine deposits are separated into two units by a reflector package (the thin stratigraphic unit, R1) that can be traced throughout the southern half of the bay on the recently acquired seismic profiles. This reflector package is shallowest along the southern edge of the bay where it onlaps the bay side of Morgan Peninsula and Dauphin Island, and it is deeper in the central part of the bay where it drapes the underlying bay-floor deposits but does not onlap older deposits along the edges of the bay. The reflector amplitude of the surface of this unit is highest 
along the southern edge of the bay and is the lowest to the north in the central part of the bay. The variation in reflector amplitude and the geometry of the unit suggest the R1 unit may be the result of increased storm activity in the bay, which resulted in increased transport of coarse material into the bay from the south. Another possible result of increased storm activity was the formation of shell lag beds from resuspension and winnowing of bay-floor sediment. Rodriguez and Meyer (2006, p. 260-266) dated the horizon at 4,300 to 3,000 years before present, during a time when Morgan Peninsula underwent severe erosion and narrowing. This erosional period in the history of the peninsula appears to be indicated in the estuarine deposits of the southern part of the bay as well. Average estuarine sedimentation rates decreased after the formation of R1; this decrease coincides with a decline in the rate of sea-level rise and appears to be controlled by accommodation space in the bay.

\section{Acknowledgments}

We appreciate the assistance provided by David Bennett, captain of the U.S. Geological Survey research vessel G.K. Gilbert; Dana Wiese, who maintained the electronics; and Chandra Dreher and Jordan Sanford, who assisted with collecting the cores. The report benefited from reviews by Lawrence Poppe and Laura Brothers.

\section{References Cited}

Balsillie, J.H., and Donoghue, J.F., 2004, High resolution sea-level history for the Gulf of Mexico since the last glacial maximum: Florida Geological Survey Report of Investigations no. 103, 66 p. (Also available at http://www.gly.fsu.edu/ donoghue/pdf/balsillie-FGS-ROI04.pdf.)

Davies, D.J., and Hummell, R.L., 1994, Lithofacies evolution from transgressive to highstand systems tracts, Holocene of the Alabama coastal zone: Gulf Coast Association of Geological Societies Transactions, v. 44, p. 145-153.

EdgeTech, 2011, Sub-bottom profiling systems: EdgeTech, accessed April 12, 2011, at http://www.edgetech.com/productlinemarine.html.

Environmental Systems Research Institute, Inc., 2011, ArcGIS: Environmental Systems Research Institute, Inc., accessed April 12, 2011, at http://www.esri.com/products/index.html. Greene, D.L., Jr., Rodriguez, A.B., and Anderson, J.B., 2007, Seaward-branching coastal-plain and piedmont incised-valley systems through multiple sea-level cycles—Late Quaternary examples from Mobile Bay and Mississippi Sound, U.S.A.: Journal of Sedimentary Research, v. 77, no. 2, February, p. 139-158.

GeoGraphix, 2008, SeisVision seismic interpretation software: Halliburton, accessed July 1, 2008, at http://www.geographix.com/solutions/geophysics/seismic-interpretationsystems/seisvision.aspx.

Isphording, W.C., and Isphording, G.W., 1991, Identification of ancient storm events in buried Gulf Coast sediments: Gulf Coast Association of Geological Societies Transactions, v. 41, p. 339-347.

Kindinger, J.L., Balson, P.S., and Flocks, J.G., 1994, Stratigraphy of the Mississippi-Alabama shelf and the Mobile River incised-valley system, in R. Boyd and B.A. Zaitlin (editors), Incised-valley systems: Origin and sedimentary sequences, SEPM Special Publication No. 51, p. 83-95. 
Li, Xu, 1994, A 6,200-year environmental history of the Pearl River Marsh, Louisiana: Baton Rouge, La., Louisiana State University Ph.D. dissertation, 208 p.

Liu, Kam-biu, and Fearn, M.L., 1993, Lake-sediment record of late Holocene hurricane activities from coastal Alabama: Geology, v. 21, September, p. 793-796.

Liu, Kam-biu, and Fearn, M.L., 2000, Reconstruction of prehistoric landfall frequencies of catastrophic hurricanes in northwestern Florida from lake sediment records: Quaternary Research, v. 54, p. 238-245.

Mars, J.C., Shultz, A.W., and Schroeder, W.W., 1992, Stratigraphy and Holocene evolution of Mobile Bay in southwestern Alabama: Gulf Coast Association of Geological Societies, Transactions, v. 42, p. 529-542.

May, E.B., 1976, Holocene sediments of Mobile Bay, Alabama, in Swingle, W.E., Swingle, H.A., Bland, D.G., Tatum, W.M., and Hughes, E.A., eds., Alabama Marine Resources Bulletin: Alabama Marine Resources Laboratory, no. 11, p. 1-25.

Milliken, K.T., Anderson, J.B., and Rodriguez, A.B., 2008, A new composite Holocene sea-level curve for the northern Gulf of Mexico: Geological Society of America Special Paper 443, p. 111.

National Oceanic and Atmospheric Administration, 2006, ETOPO2v2 global gridded 2-minute database: National Oceanic and Atmospheric Administration, accessed February 21, 2012, at http://www.ngdc.noaa.gov/mgg/global/etopo2.html.

Norris, M.W., and Faichney, A.K., eds., 2002, SEG Y rev 1 data exchange format (rel. 1.0):

Tulsa, OK, Society of Exploration Geophysicists, 45 p., accessed April 12, 2011, at http://www.seg.org/resources/publications/misc/technical-standards.

Osterman, L.E., Twichell, D.C., and Poore, R.Z., 2009, Holocene evolution of Apalachicola Bay, Florida: Geo-Marine Letters, v. 29, no. 6, p. 395-404.

Otvos, E.G., and Giardino, M.J., 2004, Interlinked barrier chain and delta lobe development, northern Gulf of Mexico: Sedimentary Geology, v. 169, p. 47-73.

Rodriguez, A.B., and Meyer, C.T., 2006, Sea-level variation during the Holocene deduced from the morphologic and stratigraphic evolution of Morgan Peninsula, Alabama, USA: Journal of Sedimentary Research, v. 76, p. 257-269.

Rodriguez, A.B., Simms, A.R., and Anderson, J.B., 2010, Bay-head deltas across the northern Gulf of Mexico back step in response to the 8.2 ka cooling event: Quaternary Science Reviews, v. 29, nos. 27-28, p. 3983-3993.

SIOSEIS, [undated], Introduction: SIOSEIS, accessed April 12, 2011, at http://sioseis.ucsd.edu/sioseis.html.

Stockwell, J.W., Jr., and Cohen, J.K., 2007, The new SU user’s manual (version 3.3): Golden, Colo., Colorado School of Mines Center for Wave Phenomena, 141 p.

Twichell, D., Edmiston, L., Andrews, B., Stevenson, W., Donoghue, J., Poore, R., and Osterman, L., 2010, Geologic controls on the recent evolution of oyster reefs in Apalachicola Bay and St. George Sound, Florida: Estuarine, Coastal and Shelf Science, v. 88, p. 385-394. 


\section{Figures}

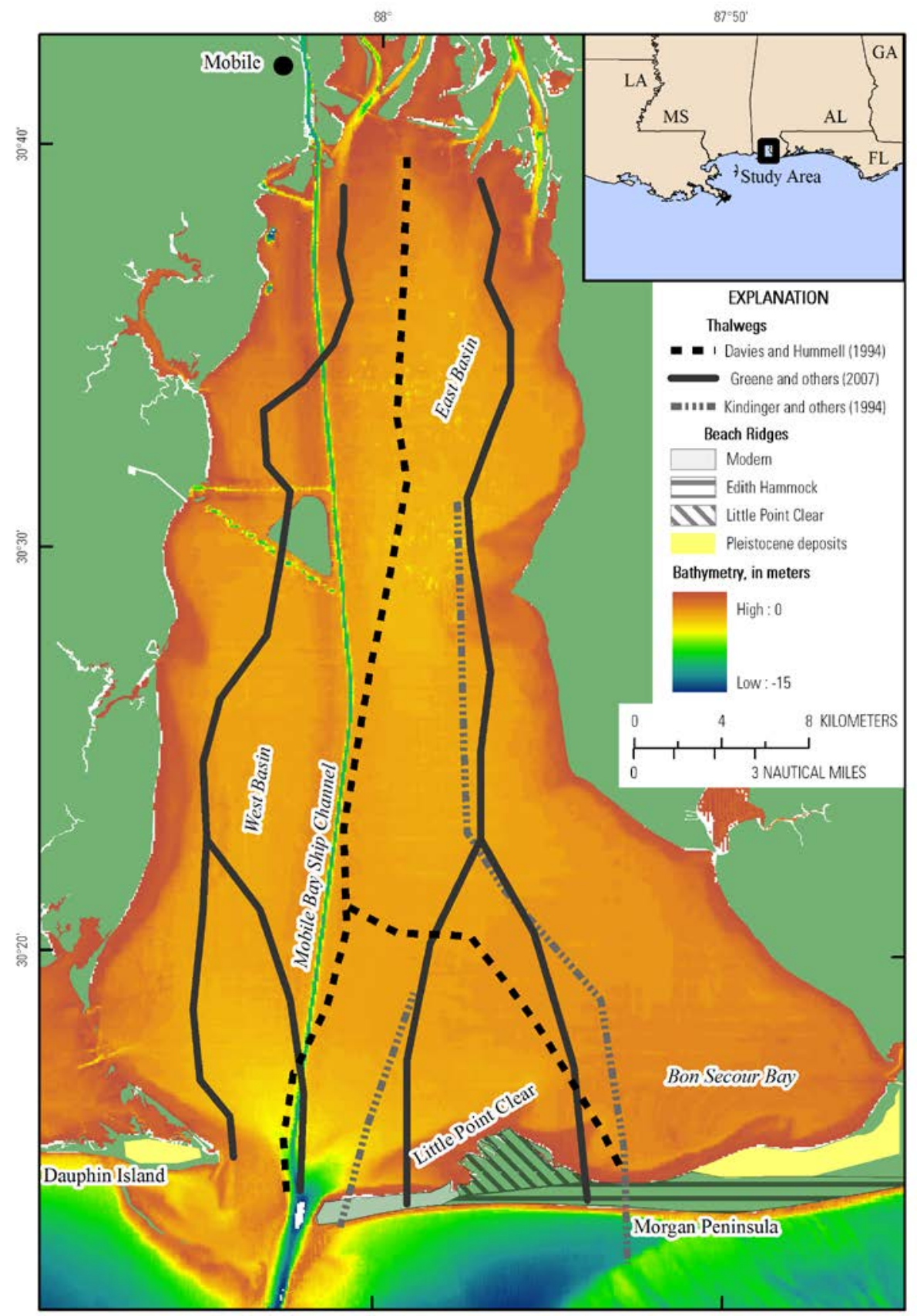

Figure 1. Map showing the bathymetry of Mobile Bay, Alabama (National Oceanic and Atmospheric Administration, 2006), the paths of lowstand river valleys, the extent of Pleistocene deposits around the bay, and the location of three sets of Holocene-aged beach ridges on Morgan Peninsula. The bathymetry of the bay is from the National Oceanic and Atmospheric Administration (2006), and the paths of lowstand river valleys are interpreted by Kindinger and others (1994), Davies and Hummel (1994), and Green and others (2007). Inset map shows the location of Mobile Bay in the northeastern Gulf of Mexico. 


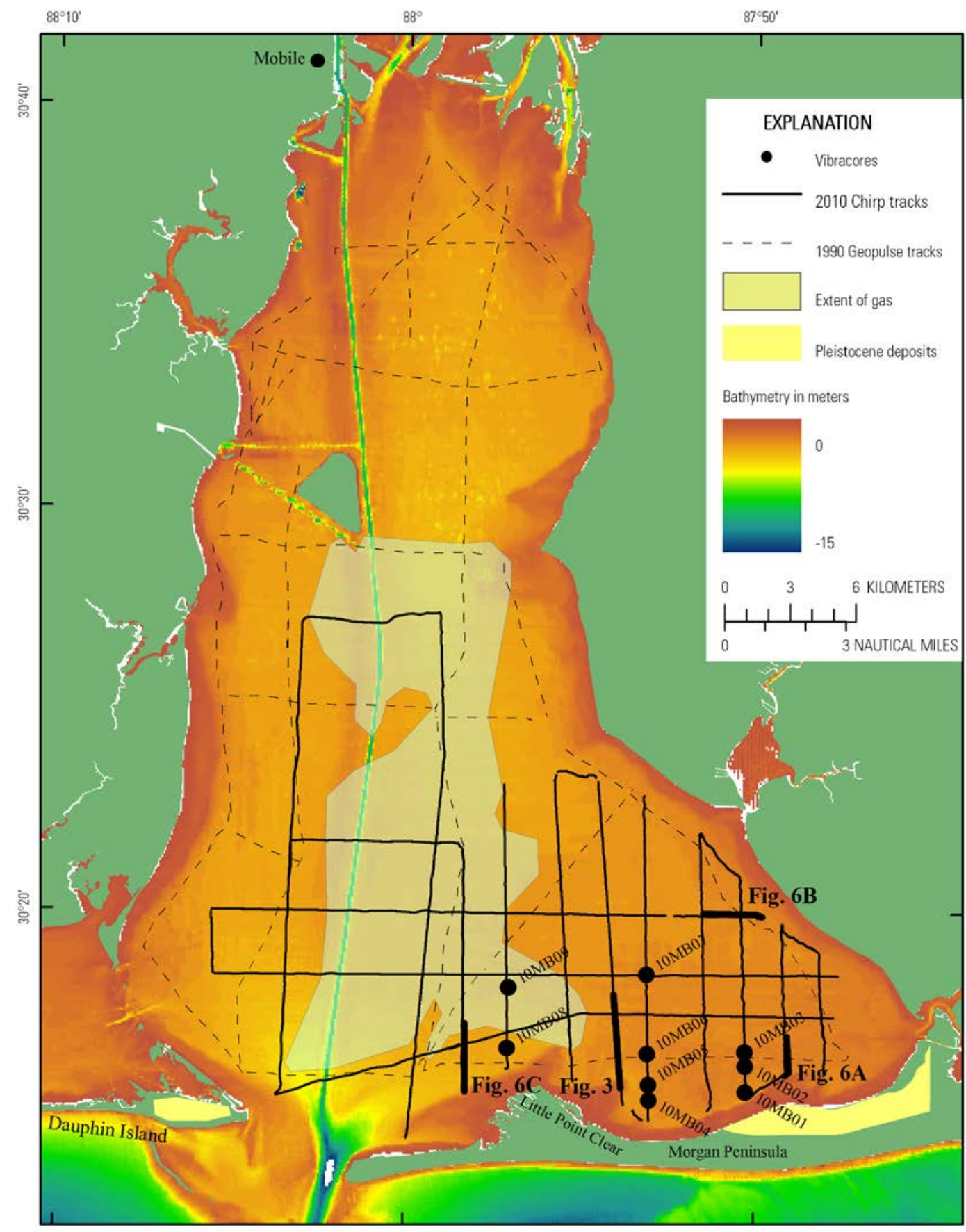

Figure 2. Map showing the extent of the seismic data and cores collected in 2010 and the tracks along which analog seismic data were collected in 1990 in Mobile Bay, Alabama. The bathymetry of the bay is from the National Oceanic and Atmospheric Administration (2006). Locations of profies in Figures 3 and 6 are shown by labeled heavy black lines. 

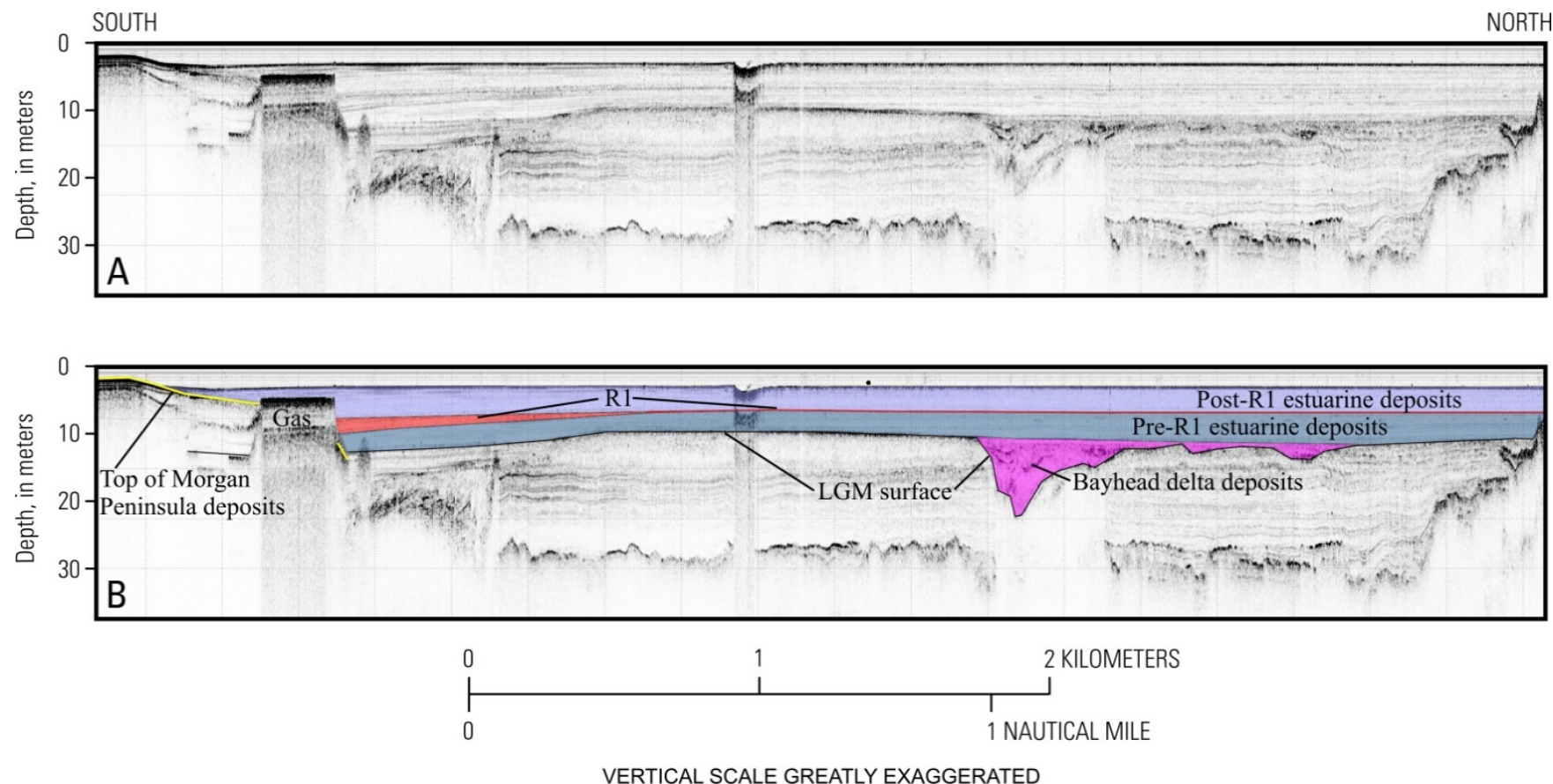

Figure 3. A, Seismic profile and B, interpretation showing the Holocene stratigraphy of Mobile Bay, Alabama, above the surface of the last glacial maximum. Profile location is shown on figures 2 and 5. 


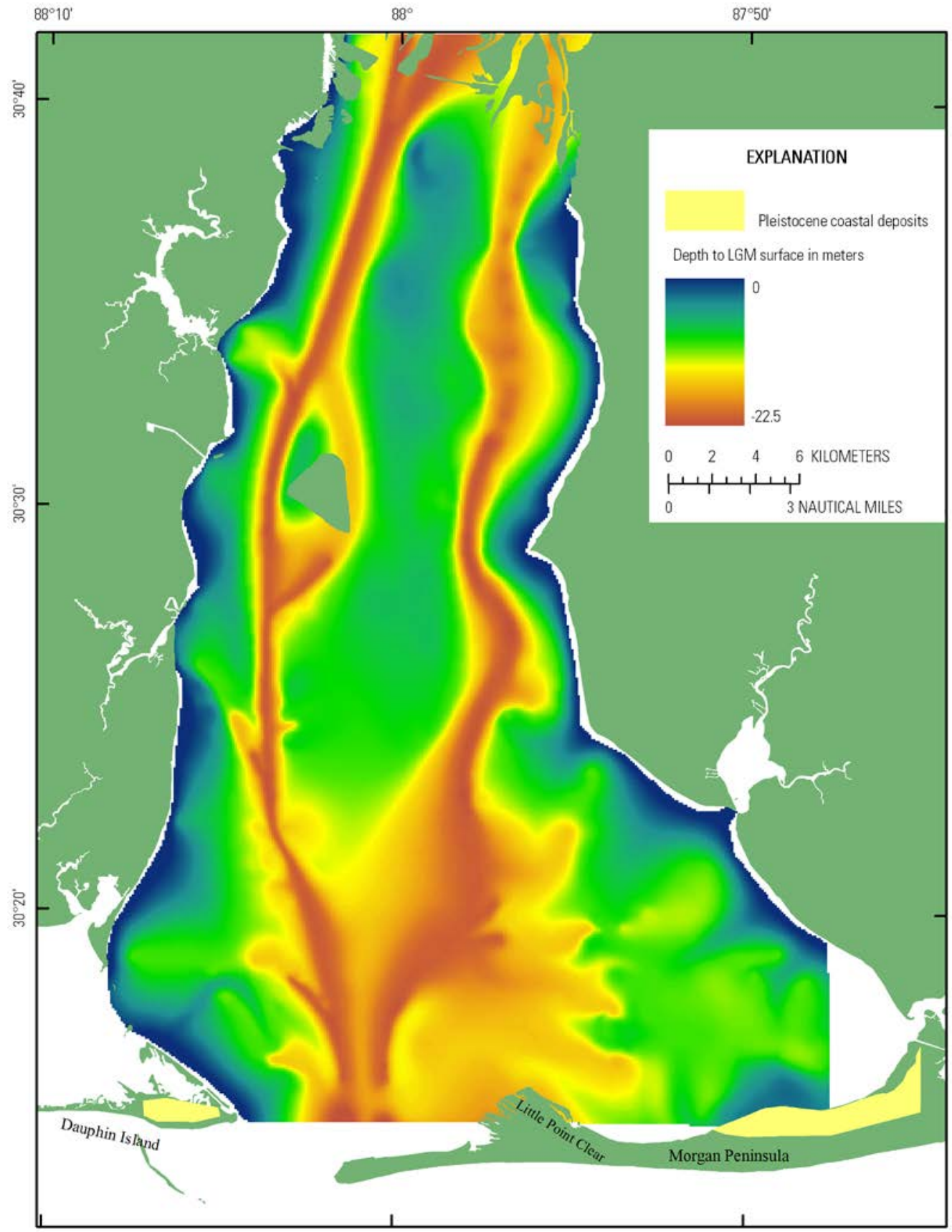

Figure 4. Map showing the depth to the erosional surface in Mobile Bay, Alabama, cut during the last glacial maximum (LGM). 


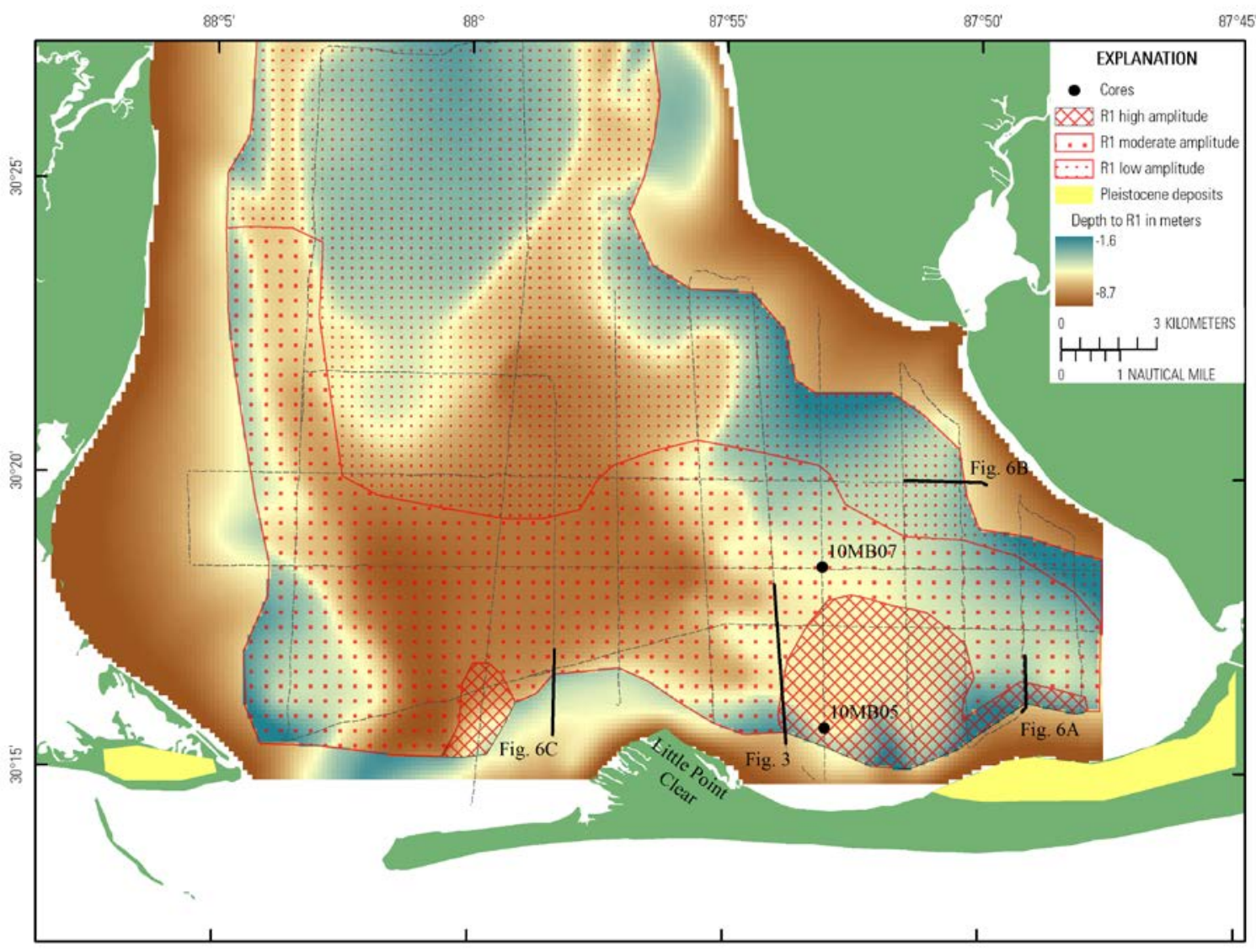

Figure 5. Map showing the depth to the top of the mid-Holocene thin R1 unit and the variations in reflection amplitude from the R1 unit in Mobile Bay, Alabama. 

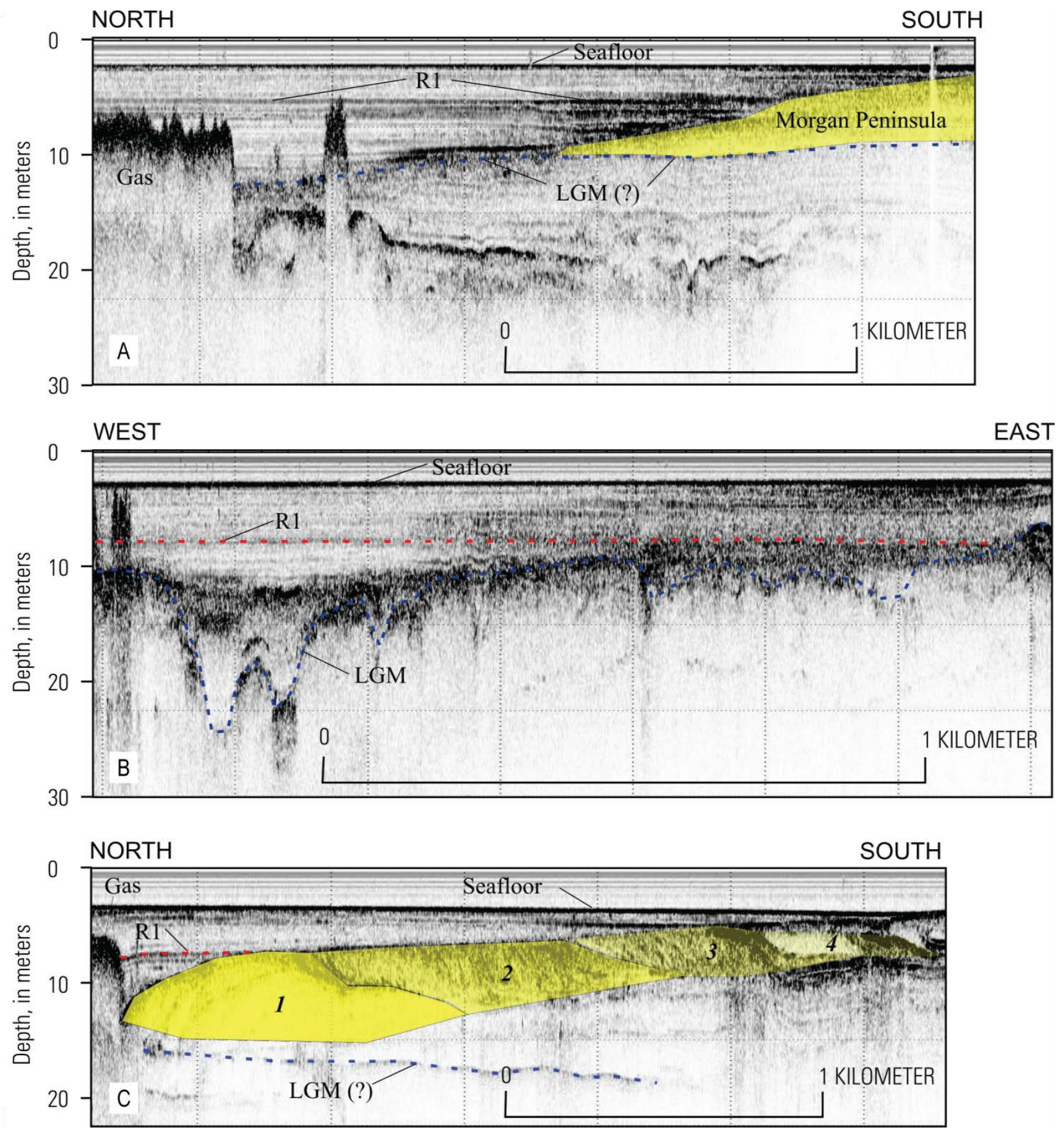

Figure 6. Seismic profiles from Mobile Bay, Alabama. $A$, Variations in reflection amplitude of the mid-Holocene thin R1 unit and how the unit onlaps the bay side of Morgan Peninsula. $B$, An east-west profile showing the flat-lying nature of unit R1 and that it pinches out on the surface cut during the last glacial maximum (LGM) along the edges of the bay. C, A crossing of the northwestern submerged extent of Little Point Clear Peninsula (yellow shading) showing the initial spit (labeled 1) and subsequent sets of southward dipping foreset beds that may represent three different stages of beach-ridge development (labeled 2, 3, and 4); the R1 unit onlaps the northern extent of the spit. Red dashed lines show R1, and blue dashed lines show the LGM surface. Profile locations are shown on figures 2 and 5. 
10MB05

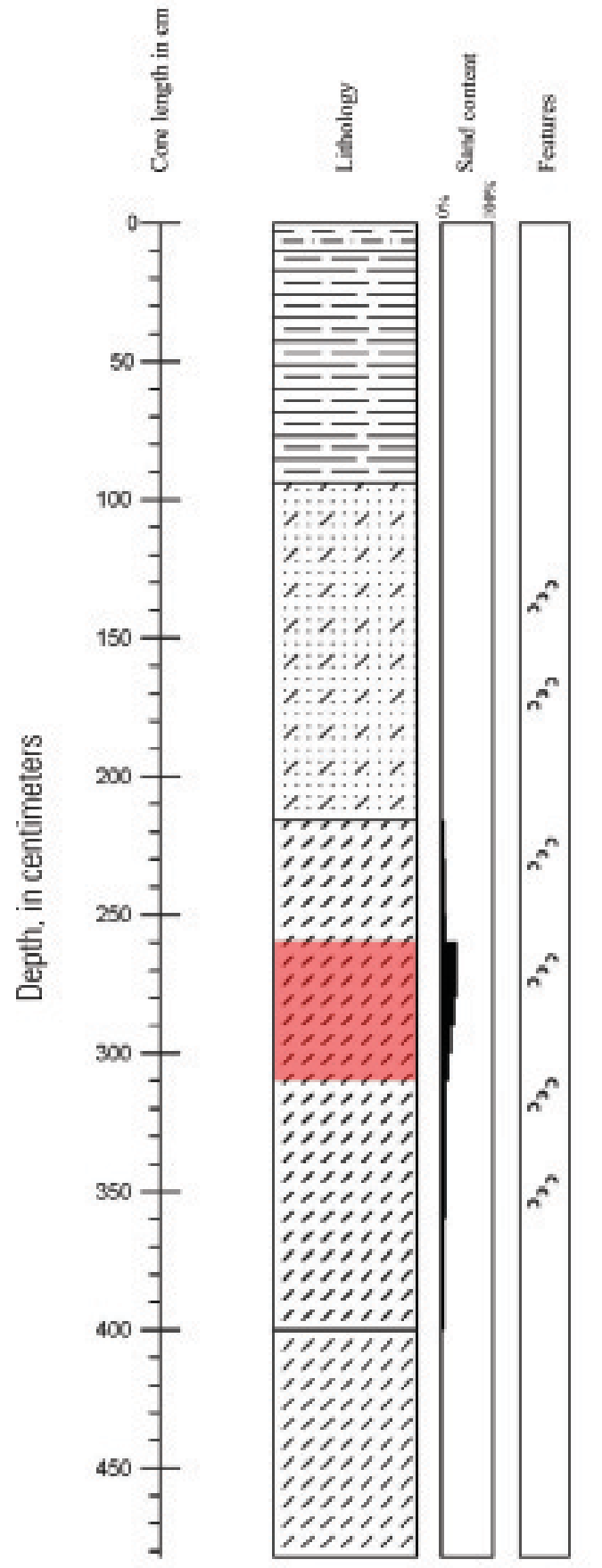

10MB07

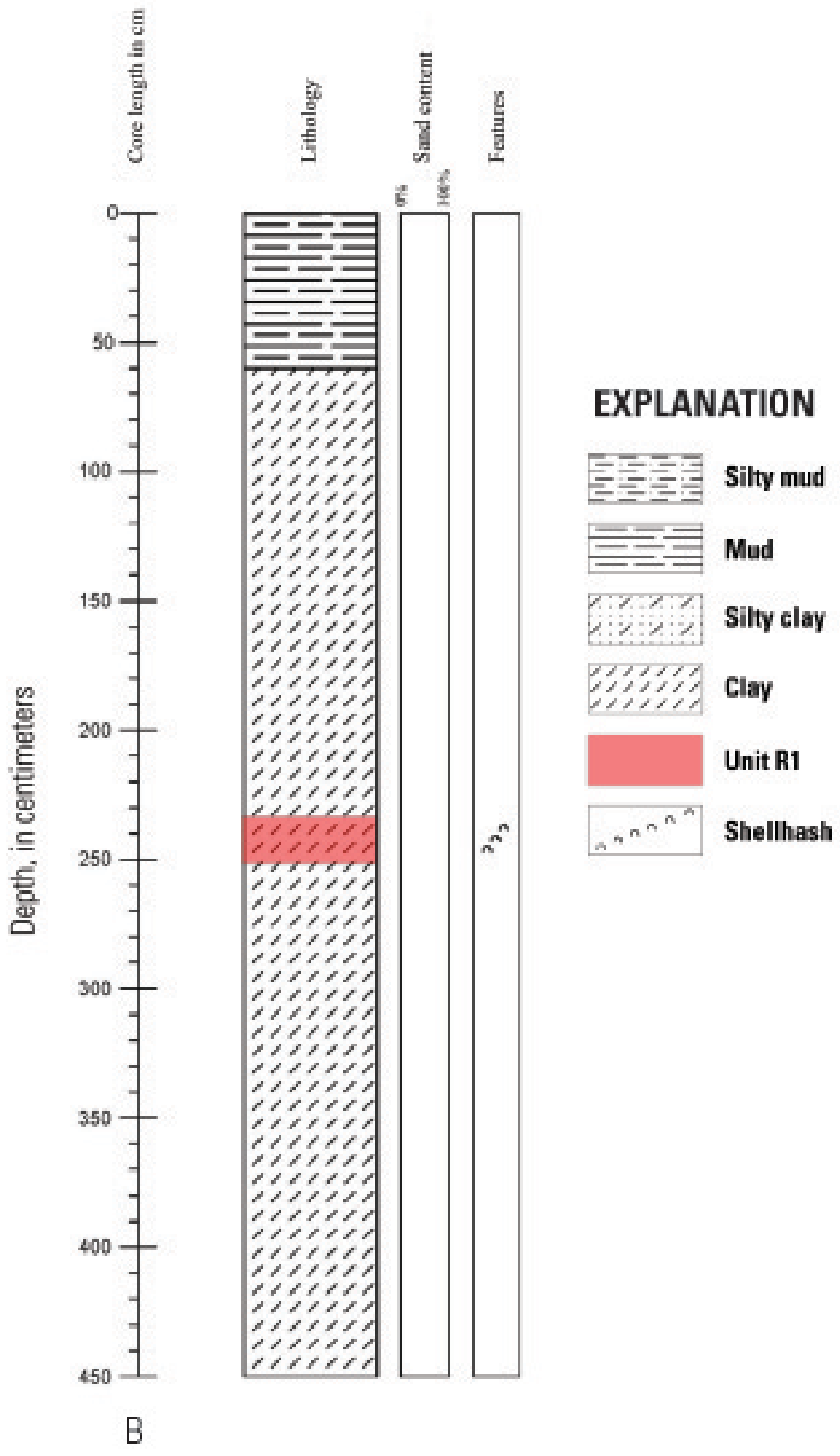

A

Figure 7. Two vibracores charts from Bon Secour Bay, Alabama, showing variations in sediment composition associated with the mid-Holocene thin R1 unit. Core 10MB05 was collected from an area where the reflection amplitude is high, and the 0.5-meter-thick sand bed corresponds to the seismic reflector. Core 10MB07 was collected from an area of moderate reflection amplitude, and a thin shell bed corresponds to the seismic reflector. Core locations are shown on figure 5. 


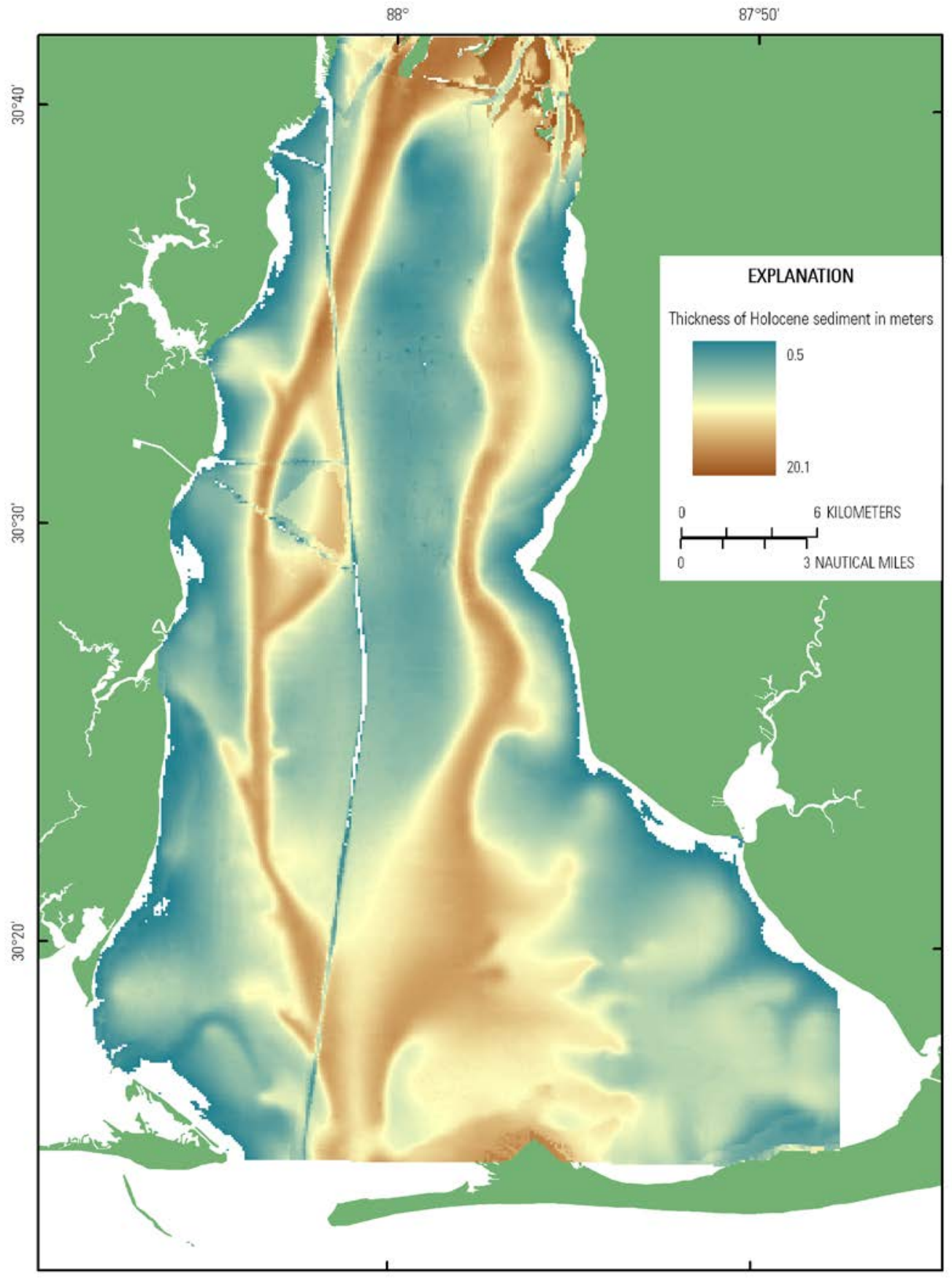

Figure 8. Isopach map showing the thickness of Holocene deposits in Mobile Bay, Alabama. 

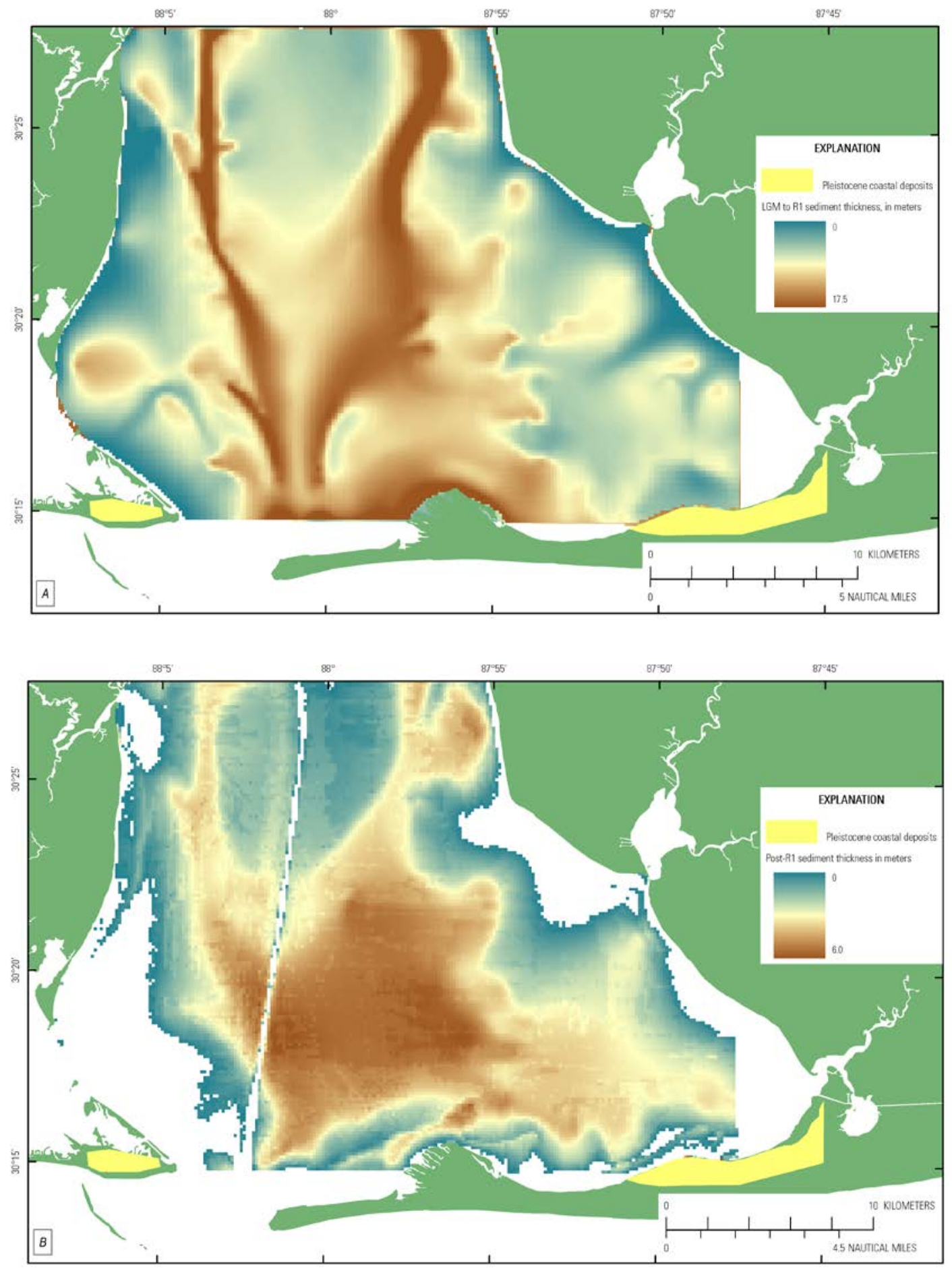

Figure 9. Isopach maps of Mobile Bay, Alabama. $A$, The thickness of early Holocene deposits that accumulated between the last glacial maximum and the surface areas of the mid-Holocene thin R1 unit. $B$, The thickness of late Holocene deposits that accumulated above the surface of the R1 unit. 
For more information concerning this report, contact

Director

U.S. Geological Survey

Woods Hole Coastal and Marine Science Center

384 Woods Hole Road

Quissett Campus

Woods Hole, MA 02543-1598

WHSC_science_director@usgs.gov

508-548-8700 or 508-457-2200

or visit our Web site at

http://woodshole.er.usgs.gov 
